would then be gradually removed by the action of rain and running water, while the angular blocks and débris would remain for a very much longer time, until eventually they crumbled down and were carried away in the form of gravel, sand, and mud. As far as one can judge from descriptions, the "stonerivers " of the Falkland Islands seem to present very much the appearance which such dessicated earth-glaciers might be expected to asstme, after their finer materials have been abstracted. The possibility that considerable masses of loose materials, such as a "soil-cap," may have moved en masse, has before now attracted the attention of some observers. Mr. Robert Mallet contributed a paper on the subject a number of years ago to the Journal of the Dublin Geological Society. (see vol, v.) ; and in the Fahrbuch der k.k. geologischen Reichsanstalt, vol. xxii. p. 309 , will be found an article by Theodor Fuchs, treating of the same subject.

Geol. Survey, Perth, N.B.

\section{Government Grants to Science}

IN that part of the article in last week's NATURE on "Govern. ment Grants" which relates to the grant which has been for some years annually voted for pathological inquiries under the direction of Mr. Simon, a statement is made concerning myself, which I fear may convey a false innpression as to the relation in which I stand to the Medical Department of the Privy Council.

Will you allow me to say that that relation is limited to the fact that the pathological investigations in question are conducted at the Brown Institution by my friend and colleague, Dr. Klein, who derives his commission directly from their lordships. I may take the opportunity of adding that the directors of the institution, of whom Mr. Simon is one, are as anxious as I am rnyself that its resources should be available, not only for this, but for all other purposes connected with the advancement of pathological science.

In former years, as your readers no doubt know, I have myself undertaken numerous investigations for the department, the last occasion occurring in 1875 , but for some time past other and equally important duties have rendered this impossible.

March 5 J. BURDON-SANDERSON

Tints and Polarisation of Moonlight in Eclipse

THE gradation of the coloured tints on the moon's surface during total eclipse was seen here most clearly last Tuesday. At the middle of the eclipse the surface seemed to be obscured by a dusky disc surrounded by a broad bright copper-coloured rim, of uniform width, following the outline of the moon's edge. Just before totality ceased the surface presented the appearance of a series of coloured crescents having the centres of their boundaries on the line joining the point where ordinary light would soon appear to the moon's centre.

The order of colour was bright sea-green at the edge, followed by a pale golden tint, then copper tints, deepening to a dusky red or peach-bloom.

The explanation of these effects of sunlight in its passage through the earth's atmosphere will be found in Herschel's Astronomy, $\S \S 42 \mathrm{I}-4$

The sky generally was free from any but very transparent clouds, and the air keen and frosty with steady breeze.

Shortly before the middle of totality I examined the light from the moon's surface by means of a double-image prism (made for solar eclipse work by Mr. Ladd) outside the eye-piece of a telescope with a $3 \frac{3}{4}$ inch object-glass. On turning the prism round, with its front surface perpendicular to the axis of the telescope, the two images of the moon, in the parts where they did not overlap, appeared to brighten and darken alternately, interchanging intensities. The cycle was completed in course of revolution through $180^{\circ}$. This is conclusive as to the polarisation of the light received from the moon during total eclipse. I was unable to determine the character of the polarisation. There will be another total eclipse on August 23, for which I hope to be better prepared.

St. John's College, Cambridge, March I

A. FreEman

\section{The Patenas or Grass Lands of the Mountain Region of Ceylon}

Everyone who has travelled through the Central Province of Ceylon must have been struck by the occurrence, apparently. without sufficient cause, of tracts of grass-land varying from a few perches to hundreds, and sometimes thousands, of acres in extent, in the midst of otherwise interminable jungle. This land is exceedingly poor; almost without exception it is worthless to the coffee-planter for purposes of cultivation, and. incapable of supporting any vegetation except its own acrid mànà grass ( $A$ n. dropogon schananthus) and a few stunted specimens of Careya arborex and Emblica officinalis. Yet on all sides of it will probably be found a rich forest vegetation that grows luxuriantly up to the very edge of the grass, where it terminates abruptly without any dwarfed or stunted undergrowih on the border-line to show that the soil gradually changes from a fertile to a sterile character. Sir Emerson Tennant, in seeking for an explanation of this curious phenomenon, appears to have been completely baffled, for he suggests nothing beyond what is contained in a quotation from Humboldt in reference to the grassy plains of South America, where that great traveller speaks of the destruc. tive custom of setting fire to the woods when the natives want to convert the soil into pasture. One reason, which seems to be quite conclusive against this explanation being applied to the grass-lands of Ceylon, is that cleared forest-land, however neglected and impoverished, does not run into grass such as is found on these Patenas, but into a dwarfish jungle called "chena," and then again, after a considerable period of time, into forest: Besides, it very frequently happens that these grasslands are the very last pieces of ground that one would expect the natives to select out of the forest to bestow labour on in clearing and burning. Another and minor argument against this view is that the natives, whose traditions extend back for a considerable period of time, can give no account of the origin of Patena-lands, as no doubt they would be able to do if their ancestors and themselves were the cause of their existence. Other causes, therefore, than that of human agency must be sought for. One of these I believe I discovered during noy residence in Ceylon, and I should be glad to learn whether any of the readeis of NATURE have noticed the same in any part of the gneiss formation of Southern India, or indeed in any extensive gneiss formation within or without the Tropics. How far this particular cause operates in other instances than the one presently to be mentioned I am unable to say, but $I$ an inclined to the belief that although it does not hold universally, it nevertheless holds pretty generally in the case of the larger patenas. It must be remem. bered that the mountain region of Ceylon is entirely a gneiss formation, very much dislocated during upheaval, and consisting at the present time of exceedingly deep valleys and precipitous mountain ranges. In this gneissic series occurs a band of halfformed quartzite several hundreds of feet in thickness, to which my attention was first attracted by noticing that below it, i.e., where its débris accumulated, nothing but patena was to be found, whilst above, where the ordinary gneiss rocks were in a state of disintegration, the jungle and coffee was of a most luxuriant character. This band of quartzite stands out from the ordinary gneiss cliffs in the valley leading from. Pussellawa to Ramboda, about twenty miles south of $\mathrm{K}$ andy. It extends for about five miles in the form of a cliff, broken through here and there by ravines. Its upper surface, beginning at an elevation of 4,500 feet on the Helbodde coffee estate, dips under the main waterfall at Ramboda, and disappears under the ordinary gneiss at an elevation of about 3,000 feet above sea-level. This rock weathers very black, and is distinguishable at a distance of several miles from the ordinary gneiss above it and in its neighbourhood. It seems to disintegrate into little else than a quartz sand impregnated with iron and entixely incapable of supporting the usual forest vegetation with which the district, except in this particular spot, abounds. I have been informed that in the extensive patena district of Ouvah, which, roughly speaking, is a plain almost surrounded by mountains, a few miles south of the district just mentioned, and separated from it by the loftiest mass of mountains in the island, the same quartzite formation occurs, but not having had an opportunity of visiting and examining it, I am unable to say how far this information is to be relied on. When one remembers how very extensively the gneiss is broken up throughout the whole of this mountain region of the Kandyan province, it seems not improbable that other patenas, especially the larger ones, owe their origin to the cropping out of this quartzite band, although it is difficult, probably impossible in many cases, to determine that such is the case.

\section{Oxford}

R. ABBAY 